\title{
EFFECT OF VERTEBRAL DEGENERATION ON THE INSTABILITY OF SPINE
}

\author{
O. Chabarova ${ }^{a}$, R. Kačianauskas ${ }^{a}$, and V. Alekna ${ }^{b}$ \\ ${ }^{a}$ Department of Applied Mechanics, Vilnius Gediminas Technical University, Sauletekio 11, 10223 Vilnius, Lithuania \\ ${ }^{\mathrm{b}}$ Faculty of Medicine, Vilnius University, M. K. Čiurlionio 21/27, 03101 Vilnius, Lithuania \\ Email: olga.chabarova@vgtu.lt
}

Received 11 December 2019; revised 1 February 2020; accepted 5 February 2020

\begin{abstract}
Insufficient exploration of the dependence between diseases of degenerative bones and the range of motion (ROM) during torsion, flexion and lateral bending limits further understanding about the lumbar biomechanics and treating of the lumbar related dysfunction. The objective of this study was to determine the effect of vertebral degradation on the instability of spine 2 motion L2-L4 segments during torsion, flexion and lateral bending by the finite element method (FEM). Three different 3D FE models comprising the healthy state and the degradation of trabecular bone and cortical bone were developed. Nonlinear numerical analyses of lumbar spine stability discovered that osteoporotic degradation can lead to critical segmental ROM and intervertebral shearing values, which results in the loss of spine stability for the case of flexion loading. Instability is caused by microscopic changes in the thickness of cortical shell. This analysis of the intervertebral shearing and ROM may be further used to diagnose such translation abnormalities like hypomobility or hypermobility.
\end{abstract}

Keywords: osteoporosis, lumbar, FEM, instability

PACS: 87.10.Kn, 87.15.A, 87.19.rm, 87.19.xr, 46.70.-p

\section{Introduction}

The key element of the human body is the spine that provides the main support for mechanical behaviour of the body, allowing it to keep functionality during the entire life period [1]. From a mechanical point of view, the spine may be considered as a column-like structure consisting of relatively stiff structural bodies, i.e. vertebrae, connected by flexible intervertebral discs (IVD). The structure, especially flexible IVD, is very sensitive to deformation. Even small changes of the geometry of elements may lead to remarkable changes of a column-like shape and, as a consequence, to the global instability.
Stability criteria are characterized by the threshold of values of deformed shape parameters. The biomechanical instability of the spine is related to the change of spine-specific geometric shape parameters like spinal motion [2]. The spinal motion is measured in degrees of the range of motion, or ROM. Finite deformations of the spine geometry lead to redistribution of forces. Because of intervertebral shear the axial load induces eccentric forces. These effects increase the shearing of the vertebrae. Changes of the shape are induced not only by shortterm life loads but also by long-term phenomena. With ageing, progressively increasing degradation of biological tissues affects all spinal units. Instability of the spine is an intensely controversial subject. 
We are interested in changes related to osteoporotic degradation. The newest statistical data shows that people with severe osteoporosis had severe degenerative changes [3]. Research of osteoporotic degradation demonstrates a decrease of mechanical prop-

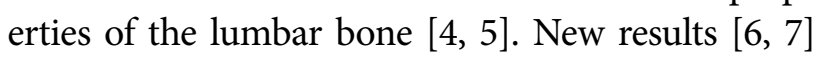
demonstrate a decrease of bone density and, as a consequence, degradation of elasticity properties. These effects lead to a visible deformation of the vertebral body, which in turn leads to a deformation of the IVD [8-10]. It can be argued that osteoporosis increases the likelihood of losing the stability of the spine and its diagnosis, especially in the aging, is difficult. However, the influence of lumbar vertebra degeneration on spinal stability has not been documented.

Different types of physiological load act on the spine, such as compression, flexion/extension, torsion and lateral bending [11]. These types of loading may essentially contribute to the behaviour of the degraded lumbar. However, little is known about the increased risk of instability.

Spinal instability is the result of deformations of all the bony and soft spinal components, therefore, application of mechanical methods and numerical modelling yield important information on deformation of the spine, which is hardly obtained by other applied methods. The numerical modelling technique of spine mechanical deformation, especially the finite element method (FEM) combined with tomography measurements, is now a quite usual research methodology. The modelling-based data is widely used to predict mechanical behaviour including instabilities.

Despite a remarkable progress in evaluating the lumbar bone tissue [9], understanding of osteoporotic changes in functionality is still not satisfactory.

Thereby, the most loaded spinal fragment is the lumbar spine, i.e. the spine fragment composed of L1-L5 vertebrae, which has to bear the essential part of the human's induced load compared to the other spinal parts [12]. In our study, we considered the lumbar spine 2 motion segments L2-L4 under the influence of compression, torsion, flexion and lateral bending loads.

The aim of this study was to evaluate the mechanical effects of osteoporotic degradation of lumbar bone tissues and their contribution to the secondary deformation of a weaker intervertebral disc and finely to instability of the spine.

\section{Modelling methods and basic data}

\subsection{Problem description}

Lumbar spine 2 motion segments comprised of three L2, L3, L4 vertebra connected by IVD are considered (Fig. 11(a)). The model of the vertebral body consists of two main constituents - a cortical shell and a cancellous core. Spinous process elements are added to reflect stiffening of the vertebra's back part. Two bony endplates are added to close a trabecular domain.

IVD is composed of nucleus pulposus, annulus fibrosus and annulus ground substance. The disc model usually discriminates between the nucleus, the annulus ground substance and annulus fibres. In the lumbar spine part, the width of nucleus is mostly between $30-50 \%$ of the whole IVD crosssection width [13-15].

Three examples of material data for the lumbar spine of 54-year-old and 69-year-old females will be considered. Here a 26 -year-old woman presented healthy spine properties.

Each of spine models are subjected to four loading cases which reflect compression load, torsion, flexion and lateral bending. While compression forces generally stiffen the spine, all other loads may be relevant with regard to spinal instability. A summary of 12 combinations of vertebra properties of loading is given in the study.

A characterization of the mechanical state of lumbar vertebrae under osteoporotic degeneration of bone tissues is performed by structural analysis, thereby applying the FEM. The choice of development of the present investigation may be motivated by the following arguments.

- New results may be obtained by exploring the already known two-phase continuum model. This two-phase - cortical shell and trabecular volume - model is mechanically reasonable and frequently explored in numerical modelling [16-20]. From a mechanical point of view, essential properties of the vertebral body can be retained when regarding it in a macroscopic scale. It was observed that osteoporotic degeneration yields macroscopic changes due to the loss of bone mass.

- Cortical bone may be modified by the socalled intracortical bone layer, where having pores increases a transition zone [21]. This implies reduction of the thickness of the cortical layer. Moreover, 
the concentrated reduction of the degraded cortical shell thickness may be considered as an imperfection and one of potential instability factors.

The internal geometry of the vertebral body is constructed to reflect both healthy state and osteoporotic degeneration. Degeneration degree is characterized by the decrease in trabecular bone density and reduction of the cortical bone thickness layer $t_{\text {cor }}$, dependent on the severity of osteoporosis.

\subsection{Problem geometry}

The lumbar spine 2 motion segment of an anatomic shape shown in Fig. 1 is considered. The lumbar body is described in Cartesian coordinates. The coordinate plane $x \mathrm{Oz}$ is a symmetry plane of the body. The trabecular volume is considered as a three-dimensional continuum while the dense cortical layer is considered as a thin shell. The geometry and dimensions of the model were obtained from high-resolution CT images. The images were reconstructed with $0.3 \mathrm{~mm}$ slice thickness and exported as DICOM files. Classification of a particular subvolume to the cortical or trabecular phase was done according to porosity (density) values [22].

Vertebral body geometry is controlled by three basic parameters. The height of the lumbar vertebral body model is approximately equal to $h=30 \mathrm{~mm}$. The cross-sectional size is approximately equal to $b=40 \mathrm{~mm}$ (Fig. 1(b)). For the healthy vertebra, the layer is $t_{\text {cor, } \max }=0.5 \mathrm{~mm}$ [23]. Various values of the minimal degenerated thickness were pointed out in accessible references [24-27], where the minimal value was $t_{\text {cor, } \min }=0.2 \mathrm{~mm}$. The thickness of the endplate is about $t_{\mathrm{pl}}=0.5 \mathrm{~mm}$. The spinous process is behind the vertebral body.

IVD was modelled to be of $h_{\mathrm{d}}=10 \mathrm{~mm}$ height and was divided into the nucleus and the annulus (Fig. 1(c)).

All major ligaments (anterior longitudinal (ALL), posterior longitudinal (PLL), capsular (CL), ligamentum flavum (LF), intertransversi (ITL), interspinuous (ISL) and supraspinous (SSL)) were represented (Fig. 1(a)).

\subsection{Mechanical properties}

The cortical phase is modelled as an isotropic elastic continuum. The trabecular phase is modelled as an elastic orthotropic continuum. Thereby, the transverse elastic modulus is assumed to be the fraction of the longitudinal modulus. The spinous process, superior articular process, transverse process and endplates are described as linear elastic isotropic material.

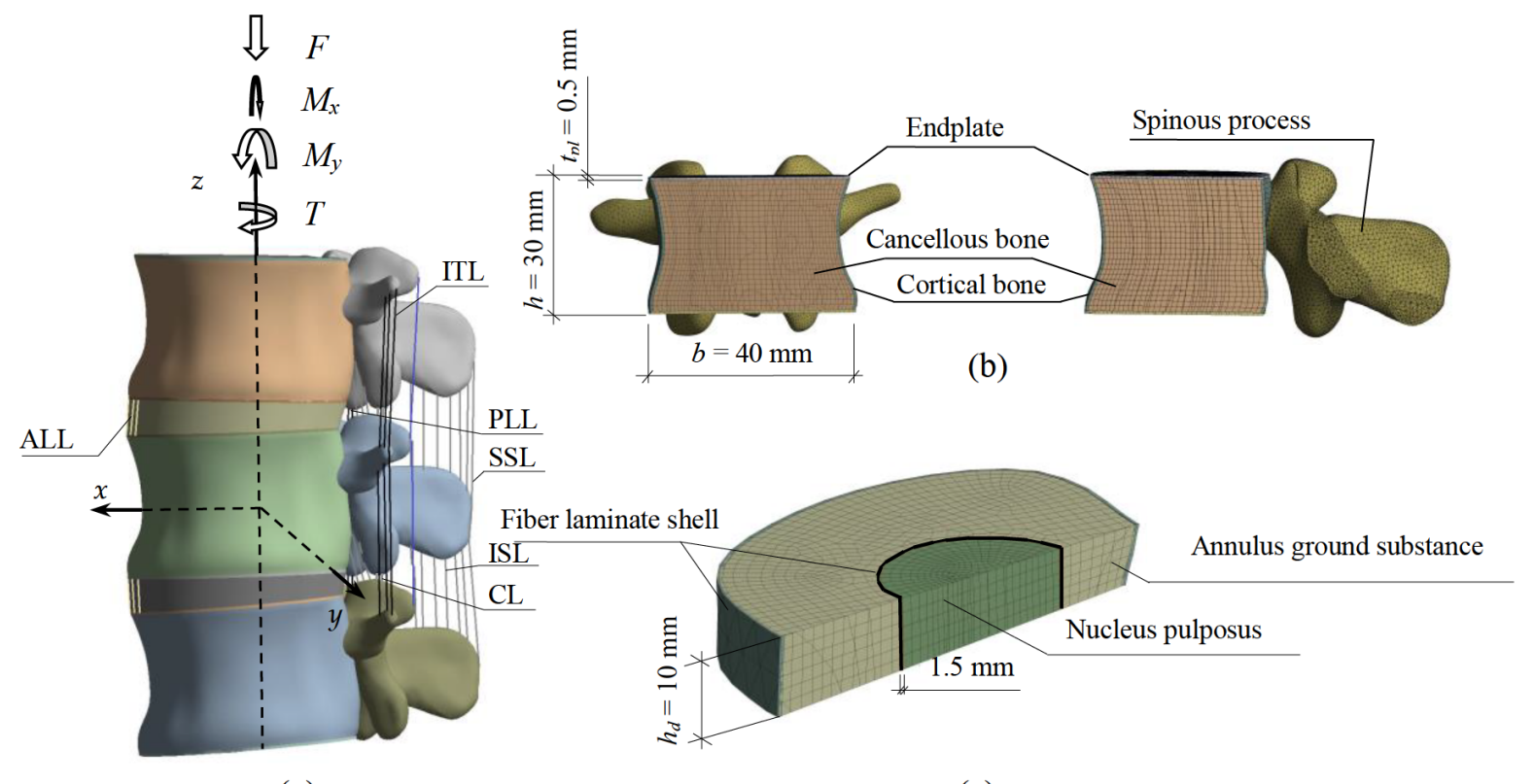

(a)

(c)

Fig. 1. A view of the models: (a) lumbar spine model of two spinal motion segments (L2-L4); (b) L3 vertebra's cross-section FE model; (c) IVD cross-section FE model. 
Material physical properties of the vertebral bones are seen in Table 1 .

The nucleus pulposus (NP) disc is an element that assures spinal stability. Its hydrostatical compression guarantees the stability of the whole disc and spine segment. NP describes linear elastic isotropic incompressible material properties. NP Young modulus is $E_{\mathrm{NP}}=1 \mathrm{MPa}$ with the Poisson ratio $v_{\mathrm{NP}}=0.4999[38-40]$. Annulus is a typical composite material consisting of annulus ground substance and annulus fibres. The isotropic neo-Hookean material relationship was assigned to the annulus ground substance model. Coefficients of neo-Hookean material are $c_{10}=0.25, D_{1}=0.86$ with the Poisson ratio $v_{\mathrm{A}}=0.4[17,41,42]$. Young modulus of the external fibre is $E_{\mathrm{EF}}=500 \mathrm{MPa}$ and the Young modulus of the internal fibre is $E_{\mathrm{IF}}=300 \mathrm{MPa}$ with the Poisson ratio $v_{\mathrm{F}}=0.3[43,44]$.

Ligaments were modelled by tensile-only uniaxial spring elements. The mechanical properties $k$ were taken from [38]. The Young modulus of liga- ments is $E_{\mathrm{ALL}}=20 \mathrm{MPa}, E_{\mathrm{PLL}}=20 \mathrm{MPa}, E_{\mathrm{CL}}=33 \mathrm{MPa}$, $E_{\mathrm{LF}}=19 \mathrm{MPa}, E_{\mathrm{ISS}}=12 \mathrm{MPa}$ and $E_{\mathrm{SSL}}=12 \mathrm{MPa}$. The Poisson ratio of ligaments is $v_{\mathrm{L}}=0.3$.

The osteoporotic ageing degeneration process is investigated by three FEM models of different grade. The Grade 1 model indicates the healthy case. Osteoporotic vertebrae degradation is characterized by decrease in porous bone density (Grade 2), also the reduction of the cortical bone thickness layer (Grade 3). The minimal value of cortical wall $t_{\text {cor, min }}=0.2 \mathrm{~mm}$ (Grade 3 ) was chosen from accessible references [24-27].

The essential characteristics of grades are seen in Table 2.

\subsection{Boundary conditions and loads}

The static boundary conditions are specified to impose the external loading. Each of the three models were considered under the action of purely axial, combined axial-torsion, axial-flexion and

Table 1. Material properties of the components.

\begin{tabular}{|c|c|c|}
\hline Bone & Young modulus (MPa) & Poisson ratio \\
\hline Cortical bone 28-30 & $E_{\text {cor }}=8000$ & $v_{\text {cor }}=0.3$ \\
\hline Cancellous bone & $E_{\mathrm{can}, x x}=33.3 / 3.5$ & $v_{\text {can }, x y}=0.3$ \\
\hline \multirow[t]{5}{*}{ (healthy [31, 32]/osteoporotic [33]) } & $E_{\mathrm{can}, y y}=33.3 / 3.5$ & $v_{\mathrm{can}, y z}=0.2$ \\
\hline & $E_{\text {can }, z z}=100 / 35$ & $v_{\mathrm{can}, x z}=0.2$ \\
\hline & $G_{\text {can }, x y}=12.8 / 1.3$ & \\
\hline & $G_{\mathrm{can}, y z}=19.2 / 2.2$ & \\
\hline & $G_{\text {can, } x z}=19.2 / 2.3$ & \\
\hline Vertebral bony endplate 34,35 & $E_{\mathrm{pl}}=25$ & $v_{\mathrm{pl}}=0.4$ \\
\hline Spinous process $[34,36,37]$ & $E_{\mathrm{pb}}=3500$ & $v_{\mathrm{pb}}=0.25$ \\
\hline
\end{tabular}

Table 2. Characterization of age-related degeneration models.

\begin{tabular}{|c|c|c|c|c|}
\hline Grades of age-related degeneration* & Vertebra & Grade 1 & Grade 2 & Grade 3 \\
\hline \multirow[t]{3}{*}{ Properties of cancellous bone } & $\mathrm{L} 2$ & healthy & osteoporotic & osteoporotic \\
\hline & L3 & healthy & osteoporotic & osteoporotic \\
\hline & L4 & healthy & osteoporotic & osteoporotic \\
\hline \multirow[t]{3}{*}{ Thickness of cortical bone [mm] } & L2 & $t_{\text {cor, } \max }=0.5$ & $t_{\text {cor, } \max }=0.5$ & $t_{\text {cor, } \max }=0.5$ \\
\hline & L3 & $t_{\text {cor, } \max }=0.5$ & $t_{\text {cor, } \max }=0.5$ & $t_{\mathrm{cor}, \min }=0.2$ \\
\hline & L4 & $t_{\text {cor, } \max }=0.5$ & $t_{\text {cor, } \max }=0.5$ & $t_{\mathrm{cor}, \max }=0.5$ \\
\hline
\end{tabular}

* Properties of bones are seen in Table 1 . 
axial-lateral bending monotonic loadings, respectively. The zero motion is specified on the bottom, while static, proportionally increasing loading is imposed by the vertical motion of the rigid upper surface of the endplate. The axial loading is controlled by the specified, monotonically increasing force $F=720 \mathrm{kN}$, while the torque is controlled by rotational moment $T=2.4 \mathrm{Nm}$, the flexion is controlled by flexion moment $M_{y}=4.8 \mathrm{Nm}$ and the lateral bending is $M_{x}=3.6 \mathrm{Nm}$. The load is transmitted to the trabecular and cortical bones through an endplate as described in [45].

\subsection{Finite element model}

Development of the FE model comprises a mathematical description of the lumbar spine and generation FE assembly. The time-dependent state of the spine 2 motion segment is obtained by formulating the nonlinear analysis problem. The behaviour of the FE model is governed by kinematic boundary conditions.

In summary, the nonlinear loading-path-dependent equilibrium is characterized by a set of nonlinear algebraic equations. The incremental formulation of this model is defined at time instant $t$ as follows:

$$
\mathbf{K}_{\mathrm{G}}(\mathbf{u}(t)) \mathbf{u}(t)=\Delta \mathbf{F}(\mathrm{t}) .
$$

Here $\mathbf{K}_{\mathrm{G}}$ is the global nonlinear stiffness matrix comprising the contribution of finite displacements and depending on the current values of displacement vector $\mathbf{u}(t)$, while $\Delta \mathbf{u}$ and $\Delta \mathbf{F}$ are increments of displacement and external load vectors, respectively. Stresses are obtained for the known values of displacements of each element separately.

Loading of the FE model is governed by static boundary conditions. Discretization of the bodies is performed by applying the preprocessor of the ANSYS code [46].

The thin-walled domain of cortical bone was discretized by shell FE. The shell element applied is a 4-node element with six degrees of freedom at each node. Such an element is associated with plasticity and larger strain and describes structure buckling. It is suitable for analysing thin to moderately thick shell structures. The FE mesh of cortical shell contains 9,669 nodes and 9,367 shell elements.
Cancellous bone, endplates, spinous process, nucleus pulposus and annulus ground substance models were meshed with volumetric FE. This type of a solid element is a higher-order 3D 20-node solid element that allows quadratic displacement approximation. The element supports plasticity, large deflection and large strain capabilities. Finally, the solid phase was described by a 3D mesh containing 710,751 nodes and 188,100 solid elements.

IVD and NP are covered by a fibre reinforced membrane. The thickness of the membrane is $1.5 \mathrm{~mm}$. The membrane is composed of four layers of fibre laminate which are stacked by $+30^{\circ}$ and $-30^{\circ}$ plies. This study used composite 4 -node shell elements to simulate the annulus fibrosus. Here, bending stiffness is neglected and only in-plane behaviour is taken into account. The FE mesh of fibre laminate contains 358 nodes and 416 shell elements. The meshed model is presented in Fig. 1(b) and (c).

Ligaments were modelled with 3-D 2-node truss elements and assigned nonlinear hypoelastic material properties.

\section{Results and discussion}

\subsection{General comments}

To evaluate the contribution of osteoporotic degradation, a series of numerical experiments using the above-discussed FE model equation (1) was considered.

The physical nature of different models is qualitatively illustrated by deformed shapes in Fig. 2, where the body $O x z$ and $O x y$ projections of the body are shown. The deformed shape is considered relative to the main axes shown in Fig. 1(a).

In Fig. 2, a comparison of the deformed shapes for different movements is presented. In the simulated osteoporotic spine, there is a higher mobility compared with healthy states for all types of loads. The first column illustrates the healthy vertebra (Grade 1), while the next subfigures illustrate degenerate vertebras. The second column reflects the results limited to the degradation of trabecular tissue (Grade 2), while the third column includes additionally the degradation of cortical shell (Grade 3). Generally, the deformed shapes reflect the deformation mode of a column-like structure where bending or torsion essentially reduces loadbearing capacity. 


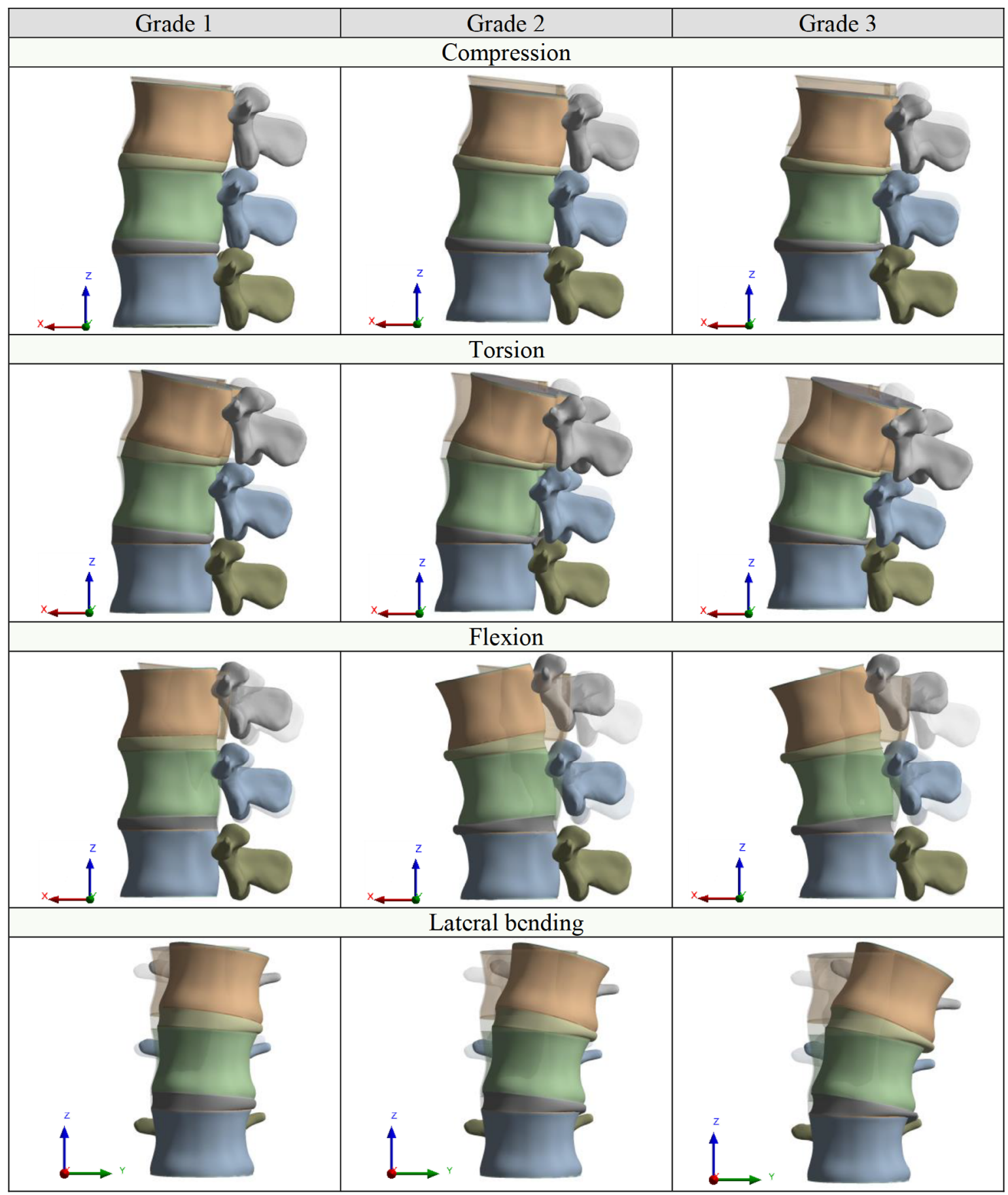

Fig. 2. The view of deformed shapes of the L2-L4 lumbar spine: a healthy model and models with osteoporotic degeneration.

The main simulation results are presented below. A detailed analysis of the deformed shape gives understanding of the instability problem.

\subsection{Deformed shape}

It is obvious that deformation of the spine increases upon application of load. Axial, torsion, flexion and lateral bending loads are the most important load cases yielding various deformation modes characterized by kinematic parameters. Full characterization of the deformed shape by various parameters occurring due to different loading is a difficult and time-consuming task. The deformation limited by ROM and intervertebral shearing is considered below. 
The aim of this study is to investigate the motion of lumbar spine segments as measured by ROM (degree). This type of deformation is due to inplane bending. The deformed shape of the central axis is transformed to a segmented line with a large offset on the top.

Graphs illustrating the ROM values of L2, L3 and L4 vertebral bodies for different load cases are shown in Fig. 3. Each graph has 4 curves: experiment, Grade 1, Grade 2 and Grade 3. The ROM values for the healthy spine (Grade 1) were compared with the experimental data [45] obtained by torsion, flexion and lateral bending. The results of FEM varied from 0.2 to $7 \%$ and fell within one standard deviation of the experimental results [45] at all levels.

In the simulated osteoporotic degradation, a higher mobility is detected at every lumbar vertebral level as compared with that of healthy conditions. Motion predicted by the finite element model compares well with the experimental results [45] at all levels.

(a)

Compression

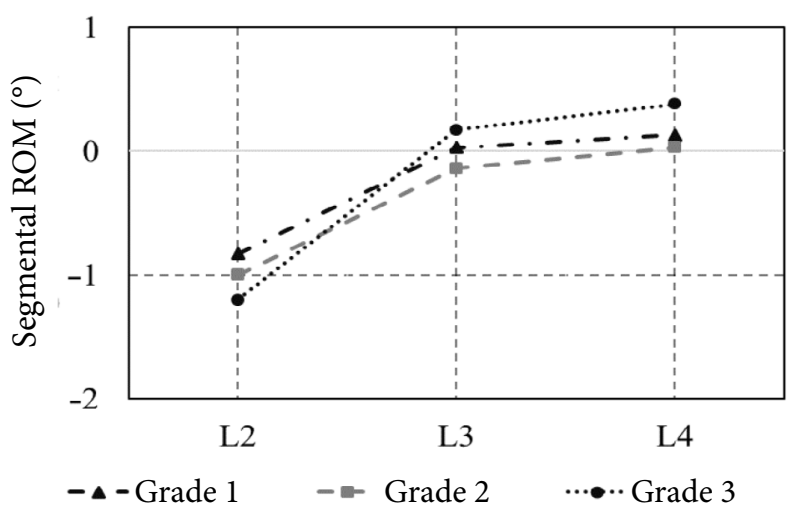

(c)

Flexion

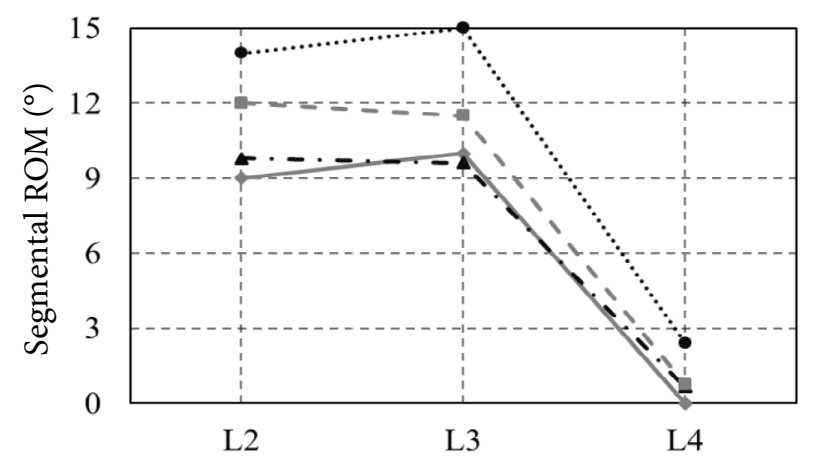

$\rightarrow$ Experimental -^ -Grade 1 -E- Grade 2 ….. Grade 3
For any grade of vertebral degeneration, under axial load, the measured segmental ROM was small with an average value of $<2^{\circ}$ (Fig. $3(\mathrm{a})$ ). In the torsion of the osteoporotic spine, the segmental ROM increases slightly, up to $5^{\circ}$, but does not reach the limit of instability (Fig. 3(b)). Under flexion (Fig. 3.(c)) and lateral bending (Fig. 3(d)) loads, the osteoporotic lumbar spine (Grade 3) loses stability, since the ROM of segments exceeds a stability limit of $15^{\circ}$ [47].

Finally, Fig. 4 shows the mobility differences between the healthy and osteoporotic L2-L4 lumbar spine.

While compressing the healthy lumbar spine (Grade 1), L2-L4 ROM is small $-1^{\circ}$. With Grade 2 and 3 compressed lumbar, ROM increases slightly, respectively, to 1.1 and $1.8^{\circ}$.

Under torsion loading (Grade 1), L2-L4 ROM slightly increased to $3.1^{\circ}$, which corresponds to the results in vitro [45]. For osteoporotic lumbar (Grade 2 and 3), ROM increased to 4.8 and $7.6^{\circ}$.

(b) Torsion

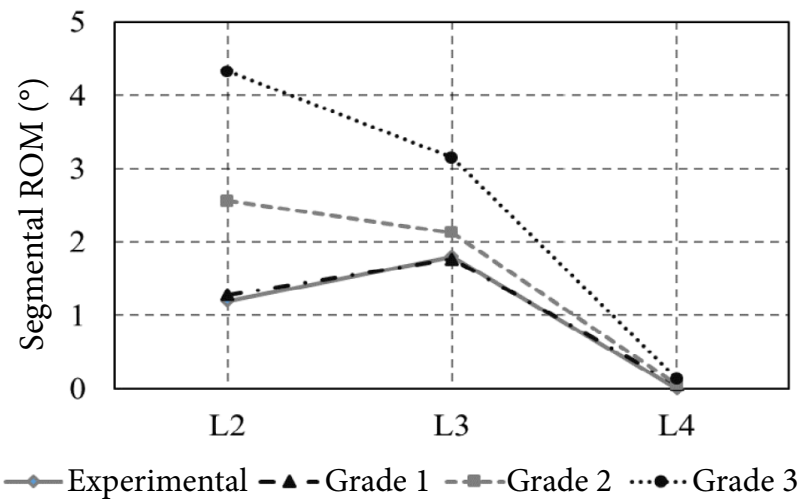

(d)

Lateral bending

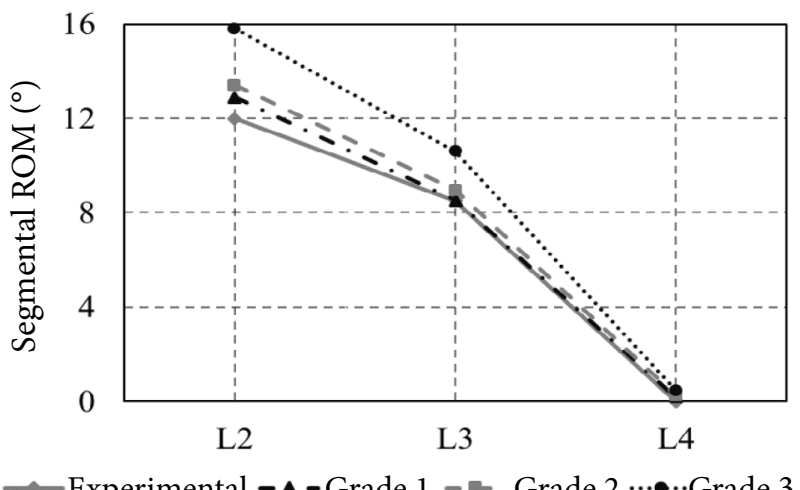

Fig. 3. ROM values of L2, L3 and L4 vertebral bodies for different load cases: (a) compression, (b) torsion, (c) flexion and (d) lateral bending. 


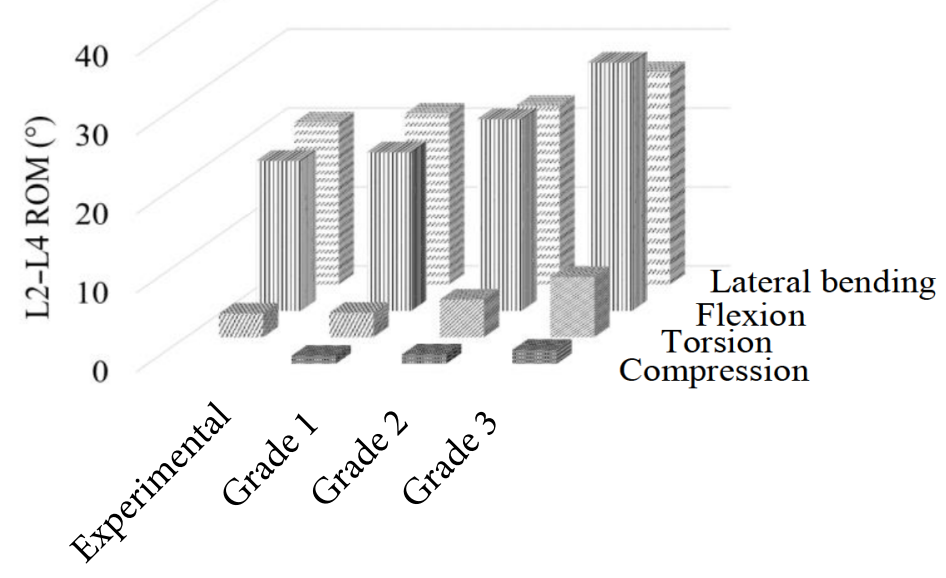

Fig. 4. Results of L2-L4 total segmental motion.

In the case of lateral bending (Grade 1), ROM greatly increased to $21.6^{\circ}$. For osteoporotic lumbar spine (Grade 3), L2-L4 ROM increased to $26.9^{\circ}$.

In the case of flexion, the L2-L4 ROM increases significantly in all grades. The Grade 3 ROM increased to $31.4^{\circ}$.

As seen from Fig. 4, the L2-L4 total segmental motion increases if a person bends down, so longterm walking with heavyweight behind the back is not recommended for people who have osteoporotic lesions as they may increase the risk of stability loss.

\subsection{Transversal shift of spine axis and instability}

Increase of osteoporotic degradation leads to the nonlinear varying compression of IVD. As a result, IVD is transformed into a trapezia shape and shearing forces occur. The shearing effect is characterized by the sheared displacement of the weakest element IVD. The values of shearing displacement of IVD are significantly large as compared with those of shearing of the vertebra. In summary, the shearing deformations result in the in-plane shift of vertebra.

The body is more sensitive to out-of-plane deformations. The shearing is characterized by shearing displacement. The values of shearing displacement are given in Fig. 5. The figure shows an insignificant contribution of osteoporosis for the case of pure axial load. For the healthy lumbar spine (Grade 1), the L2-L3 shearing is $0.36 \mathrm{~mm}$ (Fig. 5(a)) and the L3-L4 shearing is $0.002 \mathrm{~mm}$ (Fig. 5(b)). Considering the osteoporotic degen- erated lumbar (Grades 2 and 3), the main point is switched to displacement-based (shearing) criteria. The L2-L3 shearing (Grade 2) increased to $0.37 \mathrm{~mm}$ and the L3-L4 shearing increased to $0.30 \mathrm{~mm}$. When the shell thickness was reduced to $0.2 \mathrm{~mm}$ (Grade 3), the L2-L3 shearing increased to $0.46 \mathrm{~mm}$ and the L3-L4 shearing increased to $0.37 \mathrm{~mm}$.

Regarding torsion, flexion and lateral bending loading, the behaviour of lumbar is different.

Acting torsional load does not significantly increase intervertebral shearing. The L2-L3 shearing (Grade 1) increased to $0.44 \mathrm{~mm}$ (Fig. 5(a)) and the L3-L4 shearing to $0.25 \mathrm{~mm}$ (Fig. 5(b)). The L2L3 shearing (Grade 2) increased to $0.45 \mathrm{~mm}$ (Fig. 5(a)) and the L3-L4 shearing to $0.62 \mathrm{~mm}$ (Fig. 5(b)). When the shell thickness was reduced to $0.2 \mathrm{~mm}$ (Grade 3), the L2-L3 and L3-L4 intervertebral shearings increase, respectively, to $0.71 \mathrm{~mm}$ (Fig. 5(a)) and to $0.70 \mathrm{~mm}$ (Fig. 5(b)).

Acting eccentric load, such as flexion and lateral bending, greatly increases intervertebral shearing.

Under lateral bending loading (Grade 1), the L2-L3 shearing increased to $1.07 \mathrm{~mm}$ (Fig. 5(a)) and the L3-L4 shearing to $0.82 \mathrm{~mm}$ (Fig. 5(b)). For the osteoporotic spine (Grade 2), L2-L3 shearing increased to $1.39 \mathrm{~mm}$ (Fig. 5 (a)) and the L3-L4 shearing to $0.73 \mathrm{~mm}$ (Fig. 5(b)). When the shell thickness was reduced to $0.2 \mathrm{~mm}$ (Grade 3), the L2L3 shearing increased to $1.43 \mathrm{~mm}$ (Fig. $5(\mathrm{a})$ ) and the L3-L4 shearing to $0.89 \mathrm{~mm}$ (Fig. 5(b)).

In the case of flexion loading (Grade 1), the L2L3 shearing increased to $1.41 \mathrm{~mm}$ (Fig. 5(a)) and the L3-L4 shearing to $0.92 \mathrm{~mm}$ (Fig. $5(\mathrm{~b})$ ). For 
(a)

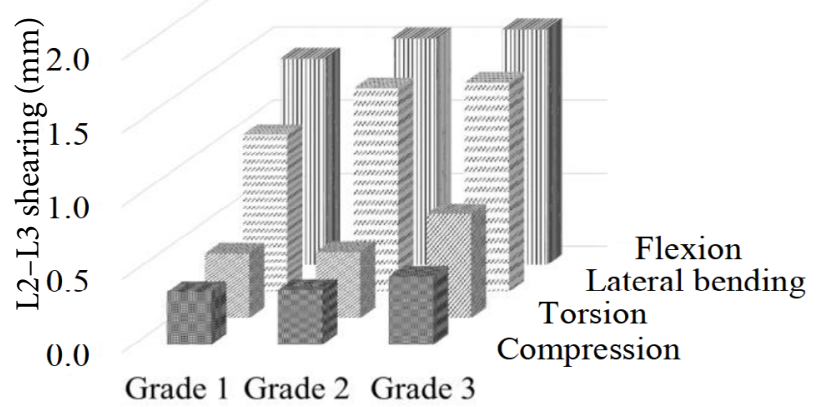

(b)

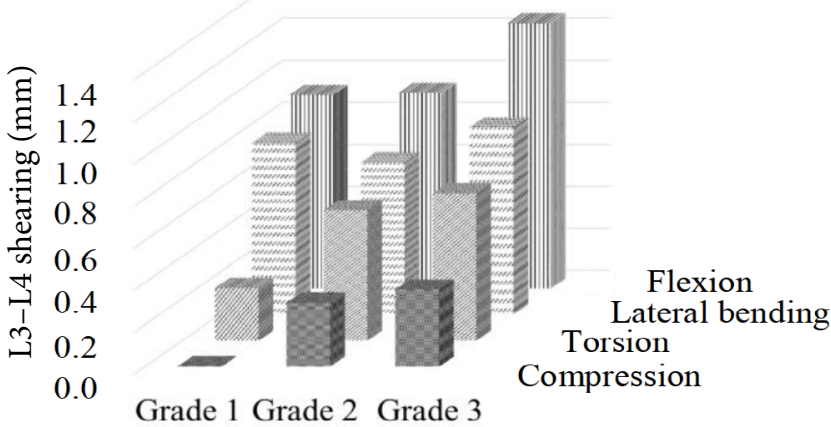

Fig. 5. Intervertebral shearing versus degeneration of aging: (a) L2-L3, (b) L3-L4.

the osteoporotic spine (Grade 2), intervertebral shearing increased even more: the L2-L3 shearing to $1.55 \mathrm{~mm}$ (Fig. 5(a)) and the L3-L4 shearing to $0.93 \mathrm{~mm}$ (Fig. 5(b)). When the shell thickness was reduced to $0.2 \mathrm{~mm}$ (Grade 3 ), the $\mathrm{L} 2-\mathrm{L} 3$ shearing tremendously increased to $1.61 \mathrm{~mm}$ (Fig. 5(a)) and the L3-L4 shearing increased to $1.26 \mathrm{~mm}$ (Fig. 5(b)).

The low trabecular bone mass density had a significant negative effect on intervertebral shearing and reducing the thickness of the cortical bone further increased the vertebrae shear. The vertebrae shear increases as well as ROM if a person bends down, which is confirmed by the numerical results. As a result, flexion and lateral bending have the greatest influence on the displacement of the vertebrae.

The numerical lumbar spine stability analyses of the considered lumbar spine 2 motion segments discovered that the presence of osteoporotic degradation, and especially a decrease in the thickness of the cortical bone, may yield catastrophic consequences in the mechanical behaviour of lumbar spine, such as increased segmental ROM and intervertebral shearing, which results in the loss of spine stability.

\section{Conclusions}

The performed FE study of lumbar spine L2-L4 subjected to four characteristic loadings discovered how osteoporotic degradation contributes to the deformation of IVD. Instability risk was evaluated by estimating ROM and shearing displacement. Osteoporotic degradation in the case of flexion and lateral bending loading increases ROM from 9 up to $15^{\circ}$, by reaching the critical segmental instability value. These results show an additional potential risk which may occur because of osteoporotic degradation. The results of this study provide important information for understanding the mechanism of loss of spinal stability in the result of degenerative changes in the bone material. Although the lumbar spine model of 2 motion segments cannot be considered as fully validated, the results obtained indicate the developmental potential of the spine affected by degenerative changes in predicting the development of clinical spinal instability. In order to obtain more accurate results, future researches should assess the influence of degenerative changes in discs, ligaments and muscles on the process of loss of spinal stability.

\section{References}

[1] N.P. Reeves, J.Cholewicki, J.H. van Dieën, G. Kawchuk, and P.W. Hodges, Are stability and instability relevant concepts for back pain?, J. Orthop. Sport. Phys. Ther. 49(6), 415-424 (2019).

[2] C.M.E. Rustenburg, S.S.A. Faraj, R.M. Holewijn, I. Kingma, B.J. van Royen, A. Stadhouder, and K.S. Emanuel, The biomechanical effect of singlelevel laminectomy and posterior instrumentation on spinal stability in degenerative lumbar scoliosis: A human cadaveric study, Neurosurg. Focus 46(5), E15 (2019).

[3] K.B. Anderson, K.L. Holloway-Kew, M. Mohebbi, M.A. Kotowicz, D. Hans, and J.A. Pasco, Is trabecular bone score less affected by degenerativechanges at the spine than lumbar spine BMD?, Arch. Osteoporos. 13(127), 1-9 (2018). 
[4] G. Maquer, J. Schwiedrzik, G. Huber, M.M. Morlock, and P.K. Zysset, Compressive strength of elderly vertebrae is reduced by disc degeneration and additional flexion, J. Mech. Behav. Biomed. Mater. 42(2015), 54-66 (2015).

[5] A. Tsouknidas, G. Maliaris, S. Savvakis, and N. Michailidis, Anisotropic post-yield response of cancellous bone simulated by stress-strain curves of bulk equivalent structures, Comput. Methods Biomech. Biomed. Engin. 18(8), 839-846 (2015).

[6] S. Nobakhti and S.J. Shefelbine, On the relation of bone mineral density and the elastic modulus in healthy and pathologic bone, Curr. Osteoporos. Rep. 16(4), 404-410 (2018).

[7] Y. Luo, Empirical functions for conversion of femur areal and volumetric bone mineral density, J. Med. Biol. Eng. 39(3), 287-293 (2019).

[8] J.-Q. Wáng, Z. Káplár, M. Deng, J.F. Griffith, J.C.S. Leung, A.W.L. Kwok, T. Kwok, P.C. Leung, and Y.X.J. Wáng, Thoracolumbar intervertebral disc area morphometry in elderly Chinese men and women: Radiographic quantifications at baseline and changes at year- 4 follow-up, Spine 43(10), E607-E614 (2018).

[9] R. Zhong, F. Wei, L. Wang, S. Cui, N. Chen, S. Liu, $\mathrm{X}$. Zou, The effects of intervertebral disc degeneration combined with osteoporosis on vascularization and microarchitecture of the endplate in rhesus monkeys, Eur. Spine J. 25(9), 2705-2715 (2016).

[10]Y.P. Sharmazanova, S.A. Miahkov, and I.R. Rybak, MRI morphometry of vertebral bodies and intervertebral discs of the lumbar spine in patients with bone mineral density disorders, Pain. Joints. Spine 2(18), 71-77 (2015).

[11]S.J. Hall, Basic Biomechanics, 7th ed. (Cenveo ${ }^{\circ}$ Publisher Services, New York, 2015).

[12]A.G. Patwardhan, K.P. Meade, and T.M. Gavin, in: AAOS Atlas of Orthoses and Assistive Devices, 4th ed., eds. J.D. Hsu, J.W. Michael, and J.R. Fisk (Elsevier Health Sciences, 2008) pp. 83-89.

[13]F. Zhang, K. Zhang, H.-J. Tian, A.-M. Wu, X.F. Cheng, T.J. Zhou, and J. Zhao, Correlation between lumbar intervertebral disc height and lumbar spine sagittal alignment among asympto- matic Asian young adults, J. Orthop. Surg. Res. 13(1), 13-34 (2018).

[14]A.J. Teichtahl, M.A. Finnin, Y. Wang, A.E. Wluka, D.M. Urquhart, R. O'Sullivan, G. Jones, and F.M. Cicuttini, The natural history of Modic changes in a community-based cohort, Joint Bone Spine 84(2), 197-202 (2017).

[15]A.J. Teichtahl, D.M. Urquhart, Y. Wang, A.E. Wluka, S. Heritier, and F.M. Cicuttini, A dose-response relationship between severity of disc degeneration and intervertebral disc height in the lumbosacral spine, Arthritis Res. Ther. 17(297), 1-6 (2015).

[16]Y. Okamoto, H. Murakami, S. Demura, S. Kato, K. Yoshioka, H. Hayashi, J. Sakamoto, N. Kawahara, and $\mathrm{H}$. Tsuchiya, The effect of kyphotic deformity because of vertebral fracture: A finite element analysis of a $10^{\circ}$ and $20^{\circ}$ wedge-shaped vertebral fracture model, Spine J. 15(4), 713-720 (2015).

[17]R. Zhu, W.-X. Niu, Z.-L. Zeng, J.-H. Tong, Z.-W. Zhen, S. Zhou, Y. Yu, and L.-M. Cheng, The effects of muscle weakness on degenerative spondylolisthesis: A finite element study, Clin. Biomech. 41(2017), 34-38 (2017).

[18]M. Kinzl, J. Schwiedrzik, P.K. Zysset, and D.H. Pahr, An experimentally validated finite element method for augmented vertebral bodies, Clin. Biomech. 28(1), 15-22 (2013).

[19]C. Lan, C. Kuo, C. Chen, and H. Hu, Finite element analysis of biomechanical behavior of whole thoraco-lumbar spine with ligamentous effect, Chang. J. Med. 2013(11), 26-41 (2013).

[20]R. Blanchard, C. Morin, A. Malandrino, A. Vella, Z. Sant, and C. Hellmich, Patient-specific fracture risk assessment of vertebrae: A multiscale approach coupling X-ray physics and continuum micromechanics, Int. J. Numer. Method. Biomed. Eng. 32(9), 1-36 (2016).

[21]R.M. Zebaze, A. Ghasem-Zadeh, A. Bohte, S. Iuliano-Burns, M. Mirams, R.I. Price, E.J. Mackie, and E. Seeman, Intracortical remodelling and porosity in the distal radius and post-mortem femurs of women: A cross-sectional study, Lancet 375(9727), 1729-1736 (2010). 
[22]E.J. Hamilton, A. Ghasem-Zadeh, E. Gianatti, D. Lim-Joon, D. Bolton, R. Zebaze, E. Seeman, J.D. Zajac, and M. Grossmann, Structural decay of bone microarchitecture in men with prostate cancer treated with androgen deprivation therapy, J. Clin. Endocrinol. Metab. 95(12), E456E463 (2010).

[23]S. Li, E. Demirci, and V.V. Silberschmidt, Variability and anisotropy of mechanical behavior of cortical bone in tension and compression, J. Mech. Behav. Biomed. Mater. 21(2013), 109120 (2013).

[24]O. Ardatov, A. Maknickas, and R. Kačianauskas, in: Mechanika'2014: Proceedings of the 19th International Conference (Technologija, Kaunas, 2014) pp. 14-19.

[25]O. Chabarova, V. Alekna, R. Kačianauskas, and O. Ardatov, Finite element investigation osteoporotic lumbar L1 vertebra buckling in a presence of torsional load, Mechanics 23(3), 326-333 (2017).

[26]M. Wierszycki, K. Szajek, T. Łodygowski, and M. Nowak, A two-scale approach for trabecular bone microstructure modeling based on computational homogenization procedure, Comput. Mech. 54(2), 287-298 (2014).

[27]K. McDonald, J. Little, M. Pearcy, and C. Adam, Development of a multi-scale finite element model of the osteoporotic lumbar vertebral body for the investigation of apparent level vertebra mechanics and micro-level trabecular mechanics, Med. Eng. Phys. 32(6), 653-661 (2010).

[28]S.M. Finley, D.S. Brodke, N.T. Spina, C.A. DeDen, and B.J. Ellis, FEBio finite element models of the human lumbar spine, Comput. Methods Biomech. Biomed. Engin. 21(6), 444-452 (2018).

[29]A. Polikeit, L.P. Nolte, and S.J. Ferguson, Simulated influence of osteoporosis and disc degeneration on the load transfer in a lumbar functional spinal unit, J. Biomech. 37(7), 1061-1069 (2004).

[30]Y.H. Kim, M. Wu, and K. Kim, Stress analysis of osteoporotic lumbar vertebra using finite element model with microscaled beam-shell trabecularcortical structure, J. Appl. Math. 2013(5), 1-6 (2013).
[31]T.-M. Guo, J. Lu, Y.-L. Xing, G.-X. Liu, H.-Y. Zhu, L. Yang, and X.-M. Qiao, A 3-dimensional finite element analysis of adjacent segment disk degeneration induced by transforaminal lumbar interbody fusion after pedicle screw fixation, World Neurosurg. 124(2019), e51-e57 (2019).

[32]E. Ibarz, Y. Más, J. Mateo, A. Lobo-Escolar, A. Herrera, and L. Gracia, Instability of the lumbar spine due to disc degeneration. A finite element simulation, Adv. Biosci. Biotechnol. 4(4), 548-556 (2013).

[33]A. Polikeit, L.P. Nolte, and S.J. Ferguson, Simulated influence of osteoporosis and disc degeneration on the load transfer in a lumbar functional spinal unit, J. Biomech. 37(7), 1061-1069 (2004).

[34]A.C. Jones and R.K. Wilcox, Finite element analysis of the spine: Towards a framework of verification, validation and sensitivity analysis, Med. Eng. Phys. 30(10), 1287-1304 (2008).

[35]N.M.B. Monteiro, M.P.T. da Silva, J.O.M.G. Folgado, and J.P.L. Melancia, Structural analysis of the intervertebral discs adjacent to an interbody fusion using multibody dynamics and finite element cosimulation, Multibody Syst. Dyn. 25(2), 245-270 (2011).

[36]S. Zahaf, H. Habib, B. Mansouri, A. Belarbi, and Z. Azari, The effect of the eccentric loading on the components of the spine, Global J. Res. Eng. 16(4), 2249-4596 (2016).

[37]M. Ghadiri, Fracture mechanics analysis of fourth lumbar vertebra in method of finite element analysis, Int. J. Adv. Biol. Biomed. Res. 2(7), 2217-2224 (2014).

[38]R.N. Alkalay and T.P. Harrigan, Mechanical assessment of the effects of metastatic lytic defect on the structural response of human thoracolumbar spine, J. Orthop. Res. 34(10), 1808-1819 (2016).

[39]S. Charosky, P. Moreno, and P. Maxy, Instability and instrumentation failures after a PSO: a finite element analysis, Eur. Spine J. 23(11), 2340-2349 (2014).

[40]H. Ng, E. Teo, and V. Lee, Statistical factorial analysis on the material property sensitivity of the mechanical responses of the $\mathrm{C} 4-\mathrm{C} 6$ 
under compression, anterior and posterior shear, J. Biomech. 37(5), 771-777 (2004).

[41]R. Fan, H. Gong, S. Qiu, X. Zhang, J. Fang, and D. Zhu, Effects of resting modes on human lumbar spines with different levels of degenerated intervertebral discs: a finite element investigation, BMC Musculoskelet. Disord. 16(221), 1-15 (2015).

[42]F. Niemeyer, H.-J. Wilke, and H. Schmidt, Geometry strongly influences the response of numerical models of the lumbar spine - A probabilistic finite element analysis, J. Biomech. 45(8), 14141423 (2012).

[43]M.B. Panzer and D.S. Cronin, C4-C5 segment finite element model development, validation, and load-sharing investigation, J. Biomech. 42(4), 480-490 (2009).
[44]W.-M. Chen, J. Jin, T. Park, K.-S. Ryu, and S.-J. Lee, Strain behavior of malaligned cervical spine implanted with metal-on-polyethylene, metal-on-metal, and elastomeric artificial disc prostheses - A finite element analysis, Clin. Biomech. 59(2018), 19-26 (2018).

[45]S.M. Renner, R.N. Natarajan, A.G. Patwardhan, R.M. Havey, L.I. Voronov, B.Y. Guo, G.B. Andersson, and H.S. An, Novel model to analyze the effect of a large compressive follower pre-load on range of motions in a lumbar spine, J. Biomech. 40(6), 1326-1332 (2007).

[46]E. Madenci and I. Guven, in: Finite Element Method and Applications in Engineering Using ANSYS ${ }^{\circ}$ (Springer US, Boston, MA, 2015) pp. 35-74.

[47]P. Gopinath, Lumbar segmental instability: Points to ponder, J. Orthop. 12(4), 165 (2015).

\title{
SLANKSTELIŲ DEGENERACIJOS İTAKA STUBURO NESTABILUMUI
}

\author{
O. Chabarova ${ }^{\text {a }}$, R. Kačianauskas ${ }^{\text {a }}$, V. Alekna ${ }^{\text {b }}$ \\ a Vilniaus Gedimino technikos universiteto Taikomosios mechanikos katedra, Vilnius, Lietuva \\ ${ }^{\mathrm{b}}$ Vilniaus universiteto Medicinos fakultetas, Vilnius, Lietuva
}

\section{Santrauka}

Degeneracinių kaulų ligų ir judesio amplitudès (ROM) priklausomybès veikiant sukimo, lenkimo ir šninio lenkimo apkrovoms tyrimų trūkumas neleidžia pakankamai tiksliai suprasti stuburo juosmens biomechanikos ir taikyti efektyvesniu juosmens disfunkcijos gydymo metodų. Šio tyrimo tikslas - baigtinių elementų metodu (BEM) nustatyti slankstelių degradacijos įtaką stuburo dviejų judamųjų segmentų L2-L4 nestabilumui veikiant sukimo, lenkimo ir šoninio lenkimo apkrovoms. Buvo sukurti trys skirtingi 3D BE modeliai, apimantys sveiką slankstelį, trabekulinio kaulo ir kortikalinio kaulo degradaciją. Atlikta stuburo juosmens dalies netiesinè skaitmeninè stabilumo analizé parodè, kad osteoporotinè degradacija, veikiant lenkimo apkrovai, gali lemti kritines segmentinio ROM ir tarpslankstelinès šlyties vertes ir dèl to gali būti prarastas stuburo stabilumas. Nestabilumą lemia mikroskopiniai kortikalinio kevalo storio pokyčiai. Ši tarpslankstelinès šlyties ir ROM analizè gali būti naudojama diagnozuojant slankstelių mobilumo, tokio kaip hipomobilumas ar hipermobilumas, anomalijas. 